\title{
TOWARDS BUSINESS EXCELLENCE. THE CASE OF POLAND ${ }^{1}$
}

\author{
Rafat Haffer \\ ${ }^{a}$ Department of General Management, Faculty of Economic Sciences and \\ Management, Nicolaus Copernicus University, Toruń, Poland, \\ e-mail: rafalh@econ.umk.pl
}

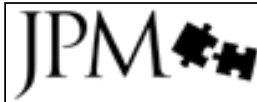

JOURNAL

OF POSITIVE

MANAGEMENT

Vol. 1, No. 1, 2010, pp. 97-109 (C) Copyright by Wydawnictwo Naukowe Uniwersytetu Mikołaja Kopernika

\begin{abstract}
The paper reports the advance of Polish companies in business excellence initiatives. It indicates how these activities influence their performance. EFQM Excellence Model indicators are used as the evaluation criteria for the study. The performance variable is introduced to ensure the calculation of correlations between EFQM model indicators and performance results. The data are next estimated as a structural equation model by partial least squares using SmartPLS software (Ringle, Wende, Will, 2005). That estimation is conducted on the model of the Danish Business Excellence Index methodology (Kristensen, Juhl, Eskildsen, 2001a). The correlations and estimation results are used to discuss the condition of Polish companies and to point out the efforts that should be made for further development. The presented data were collected by means of a structured questionnaire which was sent to companies in the year 2005. The examined sample consisted of 79 companies coming from different areas of Poland representing 19 sectors. It appears from the data that the efforts of Polish companies undertaken in most areas of self-assessment according to the EFQM model do provide them with economic value. Nevertheless, people, people results and customers' results are the areas which need the improvements to be made. At the same time they can be treated as potential for future growth.
\end{abstract}

Keywords: Poland, EFQM Excellence Model, Danish Business Excellence Model, Polish companies' efforts in developing business excellence

Paper type: Research paper

\section{Introduction}

Within recent decades Polish companies have made considerable progress in introducing and developing quality management systems. At the beginning of the 1990s Polish companies' own quality assurance systems predominated, the second half of the 1990s was characterised by the expansion of ISO 9000 series systems, the beginning of the twenty-first century was the time of making the first step in the direction of Total Quality Management (TQM). Polish leading firms have entered the path to TQM introducing TQM as a coherent concept but more often adopting

${ }^{1}$ The present article was delivered by the author as a paper entitled: Business excellence practices in Polish companies during $11^{\text {th }}$ World Congress for Total Quality Management in Wellington in 2006. 
TOWARDS BUSINESS EXCELLENCE

Rafał Haffer some important TQM principles (Haffer, 2002). It appears that Polish companies duplicate the path of quality management systems' development worked out by the majority of companies from developed countries which is clearly marked out by the market pressure on increased performance of both quality systems and the whole company (Haffer, 2005). One of the stages on that path is undertaking a self-assessment process against the criteria of the holistic leadership model which provides an objective, systemic measure of an organization's strengths and areas of improvement, and gives rise to the establishment and implementation of action plans, integrated in business planning (Porter, Tanner, 1996).

Apart from commonly used holistic leadership models like the European Foundation for Quality Management (EFQM) Excellence Model or Malcolm Baldrige Excellence Model, Polish companies have in their disposal the Business Excellence Model based on the Polish Quality Award which is called the Management Improvement Model (MIM). The concept of Management Improvement Model (MIM) was elaborated under the direction of professor E. Kindlarski from the Quality Committee of National Chamber of Commerce in 1995. The same year the Polish Quality Award was established. To create MIM, materials and documents of the Deming Application Prize (DAP), the Malcolm Baldrige National Quality Award (MBNQA) and the European Quality Award (EQA) were used. However, the philosophy of EFQM Excellence Model was the fundamental one as it was the most convergent with intention of the authors of MIM. Nowadays, the Committee of Polish Quality Award offers assessment methodologies for different kinds of organizations, namely: production and service organizations, public organizations (health care, governmental administration) and educational organizations. The prizes are awarded on the regional and national levels. Every year, starting form 1995, approximately 100-150 organizations compete for the Polish Quality Award which reflects the scale of that phenomenon in Poland. It means that self-assessment against the Excellence Model is still not very popular among managers in Poland. Nevertheless, business excellence practices get more intense in Polish companies even without the intentional usage of the self-assessment model. Very often it results from the efforts made by Polish companies with a view to increasing the level of management by applying the most commonly used ISO 9000 series or other management models like TQM or Balanced Scorecard (BSC). Such efforts are also undertaken in companies operating without any management model.

The present paper shows the results of the self-assessment made by Polish companies against the EFQM model criteria as well as the relationships between firms' activity in key areas of self-assessment and their performance. The performance variable is introduced to ensure the calculation of correlations between EFQM indicators and performance results. The data are next estimated as a structural equation model by partial least squares using SmartPLS software. 
That estimation is conducted on the model of the Danish Business Excellence Index methodology. The correlations and estimation results are used to discuss the question of progress in quality management among Polish companies and to point out the efforts which should be made for further development. The examined sample of companies consists of three groups. The first one is composed of firms that do not apply a holistic leadership model (46 percent). The next two groups are firms that apply a holistic leadership model (54 percent), in particular, the second group - firms that apply ISO (44 percent) and the third group - firms that apply BSC, Excellence Model or TQM (10 percent). It is assumed that in the case of each company, even if it does not apply the Business Excellence Model, it is possible to assess an organization's progress towards excellence.

\section{Survey methodology}

The data were collected by means of a structured questionnaire which was sent in the year 2005 to various companies operating in Poland. The examined sample consisted of 79 companies coming from different areas of Poland representing 19 sectors. The representatives of top management were asked to evaluate, using a 0-100 scale, the advance of companies they manage in business excellence initiatives, regardless of whether they apply any of the holistic leadership models or not. EFQM Excellence Model indicators were used as the evaluation criteria for the study. The measurement scales included 51 sub-criteria constituting 9 more aggregate criteria identical with nine elements of the EFQM Excellence Model. Following these criteria, respondents were able to assess an organization's progress towards excellence. These evaluations were then linked with the performance variable. All variables used in the paper along with the descriptions of measurement scales are presented in Table 1.

The variables shown in Table 1 are classified according to three categories: Business Excellence Model (BEM) variables, performance variables and explanatory variables.

BEM variables indicate what efforts Polish companies make on their path to excellence in the main areas of self-assessment even if they do not apply any of the excellence models. For this purpose the methodologies of the EFQM Excellence Model and the Danish Business Excellence Index (DBEI) were used. The last one served as a proposal of how to link the nine areas of the EFQM model in order to understand the interrelationship between them. Greater comprehension of the linkages between the elements that compose the model facilitates the guiding role that the award models, such as the EFQM, play in the implantation of Total Quality Management (TQM) systems. Thus, as Eskildsen and Dahlgaard (2000) assert, knowledge about the causal structure of the model allows organizations to benefit fully from the self-assessment processes and improve the management of the business. 
TOWARDS BUSINESS EXCELLENCE

Rafał Haffer
No. Variables The descriptions of variables and measurement scales

Business Excellence Model (BEM) variables

The variables that express management executives' evaluation of the activity their companies undertake in each of the nine areas of self-assessment

EFQM according to the EFQM model, namely, leadership, policy and strategy,

Excellence people, partnerships and resources, processes, customer results, people Model indi- results, society results, key performance results (based on a 0-100 scale, in cators which its extreme values mean respectively: 0 - lack of activity in a certain self-assessment area, 100 - a maximum level of a firm's activity in a certain self-assessment area).

\section{DBEI}

indicators

(Danish

2 Business

Excellence

Index indicators)

BE

3 (business excellence)

The variables that express management executives' evaluation of the activity their companies undertake in each of the four areas of self-assessment according to the Danish Business Excellence Index, namely, management, people, systems, results (based on a 0-100 scale, in which its extreme values mean respectively: 0 - lack of activity in a certain self-assessment area, $100-$ a maximum level of a firm's activity in a certain self-assessment area).

The variable that expresses management executives' average evaluation of their organizations' progress towards excellence according to the EFQM model (based on a 0-100 scale in which its extreme values mean respectively: 0 - lack of progress, 100 - maximum progress towards excellence). Performance variables

The variable expresses management executives' opinions of a firm's total FTP performance in financial and market aspects over the past three years (firm's total concerning in particular changes in sales revenue, profit and market share, 4 performan- in absolute and relative (in comparison to competitors) measures (based on ce) a 0-100 scale, in which its extreme values mean respectively: 0 - lack of a change for the better, 100 - a strong change for the better).

The variable expressing actual financial results of companies, created on

5 FR (finan- the basis of objective financial data (net profit, net assets, sales revenue)

cial results) which were obtained from 52 participants of the research (so from the majority of the sample).

Explanatory variables

\begin{tabular}{ll}
\hline & \multicolumn{1}{c}{ Explanatory variables } \\
\hline $\begin{array}{l}\text { MM (ma- } \\
\text { nagement } \\
\text { model) }\end{array}$ & $\begin{array}{l}\text { The variable informing of a firm's use of one or more of management mo- } \\
\text { dels like the Balanced Scorecard, Excellence Model, the Malcolm Baldrige } \\
\text { Model, ISO or TQM (based on two-grades scale <0, 1>, in which 0 means } \\
\text { that firm does not apply a management model, 1 - that firm applies a mana- } \\
\text { gement model). }\end{array}$ \\
\hline $\begin{array}{l}\text { EA (em- } \\
\text { ployees' } \\
\text { abandon- } \\
\text { ment) }\end{array}$ & $\begin{array}{l}\text { The variable expresses management executives' opinions of seriousness of a } \\
\text { problem their companies have with employees' abandonment (based on } \\
\text { a 0-100 scale, in which its extreme values mean respectively: } 0 \text { - a lack of a } \\
\text { problem, 100 - a maximum level of seriousness of a problem with employ- } \\
\text { ees' abandonment). }\end{array}$ \\
\hline $\begin{array}{l}\text { RCSS (re- } \\
\text { sult depen- } \\
\text { dent salary } \\
\text { system) }\end{array}$ & $\begin{array}{l}\text { The variable informs of a firm's use of a salary system dependent on re- } \\
\text { sults (based on two-grades scale }<0,1>\text { in which 0 means that firm does not } \\
\text { apply a result dependent salary system, 1 - that firm applies a result depen- } \\
\text { dent salary system). }\end{array}$ \\
\hline
\end{tabular}

Table 1.

The list of variables and descriptions of measurement scales 
The performance variables are introduced to examine the linkages between BEM variables and performance results and to test whether the objective measures constituted a key element of the respondents' subjective assessments. A firm's total performance (FTP) is an additional performance variable apart from the four EFQM Excellence Model indicators expressing the results concerning employees, customers, society and the whole of the business. It differs from the key performance results indicator as it measures a firm's total performance over the past three years, not only in financial but also in market aspects, which means that statements concerning sales revenue and market share are also included in the FTP variable. Nevertheless, FTP correlates significantly with key performance results $(r=0,78, p<=0,001)$, which increases the reliability of obtained results. Financial Results (FR) is an aggregate variable combining three kinds of actual objective financial data, namely, net profit, net assets and sales revenue. This objective financial measure was calculated only for 52 participants of the research, mainly because it included many private firms that as a rule, within their policies, do not provided confidential financial information. Information concerning actual financial results of the companies is included in the paper in order to discuss the possibility of using the results gathered with the aid of the Business Excellence Model methodology as a proxy for actual financial results of Polish companies.

The explanatory variables are used in order to shed light on the causes of the results obtained while correlating the BEM variables with the performance variables. The author's intention was to show how applying a management model like the Balanced Scorecard, Excellence Model, Malcolm Baldrige Model, ISO or TQM can influence a firm's activity in the self-assessment areas and achieved results. For this purpose the management model (MM) variable was developed. Furthermore, two other explanatory variables - employees' abandonment (EA) and result dependent salary system (RCSS) were introduced to the study. They are used in the paper for a better explanation of the role people management plays in the improvement process.

Additionally, Cronbach alpha coefficients were computed to test the reliability of the EFQM Excellence Model scales (Cronbach, 1951). Typically, these coefficients should fall within a range of 0.70 to 0.90 for narrow constructs such as those defined for the study, and 0.55 to 0.70 for moderately broad constructs. In the empirical study, the coefficients for the nine variables ranged between 0.87 and 0.90 . Thus, the reliability test of the EFQM Excellence Model scales worked out successfully.

\section{EFQM Excellence Model versus Danish Business Excellence Index}

The main purpose of the European Quality Award is to recognize the organizational excellence in European companies. The EFQM Excellence Model is the framework behind this award and it has clearly become the most commonly applied model in 
TOWARDS BUSINESS EXCELLENCE

Rafał Haffer
Europe for Total Quality Management (Westlund, 2001). The EFQM Excellence Model comprises nine elements grouped under five 'enabler' criteria (leadership, policy and strategy, people, partnerships and resources and processes) and four 'result' criteria (customer results, people results, society results, key performance results). The enablers represent how the organization operates, and the results concentrate one the achievements towards organizational stakeholders, and how they can be measured and targeted (EFQM, 1999). The EFQM Excellence Model is based on the logical assumption that there is an internal structure between the enabler criteria, which could be expressed as follows: leadership drives policy and strategy, people management and partnerships and resources, and these three elements influence the results through suitable processes (EFQM, 1999). Another definition of the model suggests that excellent results with respect to performance, customer, people and society are achieved through leadership driving policy and strategy, partnerships and resources, and processes (EFQM, 1999). This balanced approach allows the synergies between the elements of the model to be optimised (Westlund, 2001), which is in accordance with the global orientation postulated by the model. A balanced development implies en enabler internal structure, according to which the maximum improvement in the results is obtained only when the contributions of all enablers are the same. The EFQM Excellence Model - like other quality award models such as the Malcolm Baldrige National Quality Award in USA or Deming Application Prize in Japan is based on self-assessment. Self-assessment implies a comprehensive and regular review of an organization's activities and results against the criteria of the model (Conti, 1997). The model specifies, through its enabler criteria, the areas that the organization should consider in order to improve its results, as well as the results indicators that must be considered for excellence to be achieved. Each criterion is broken down into several sub-criteria and each sub-criteria is illustrated with various "guidance points" that exemplify what the organization has to do in order to develop the criteria. (FEQM, 1999). Thus, the self-assessment process allows a methodology to be adopted that will assess progress towards TQM/Excellence on a regular basis by providing a comparison of scores from assessments to track the real improvement achieved (van der Wiele, Dale, Williams, 2000).

The Danish Business Excellence Index was published by Danish Association for Quality Management in association with the Aarhus School of Business and the independent market research company, Markeds/Consult A/S in order to establish on overall benchmarking system for Danish companies based upon the principles of business excellence. The ideas behind the index were introduced and discussed in Kristensen and Juhl (1999) as well as in Kristensen, Juhl and Eskildsen (2001a; 2001b; 2003). The EFQM model was chosen as an obvious starting point for developing a measurement system for business excellence since the EFQM model is the most popular tool for self-assessment in Europe. It appears from the survey 
conducted by EFQM that almost 60 percent of the companies conducting selfassessment were using the EFQM Excellence model (Hakes, 1997). The nine criteria in the EFQM model have been recognized and are assumed to reflect four underlying constructs (management, people, systems and results) with an interrelationship as indicated in Figure 1.

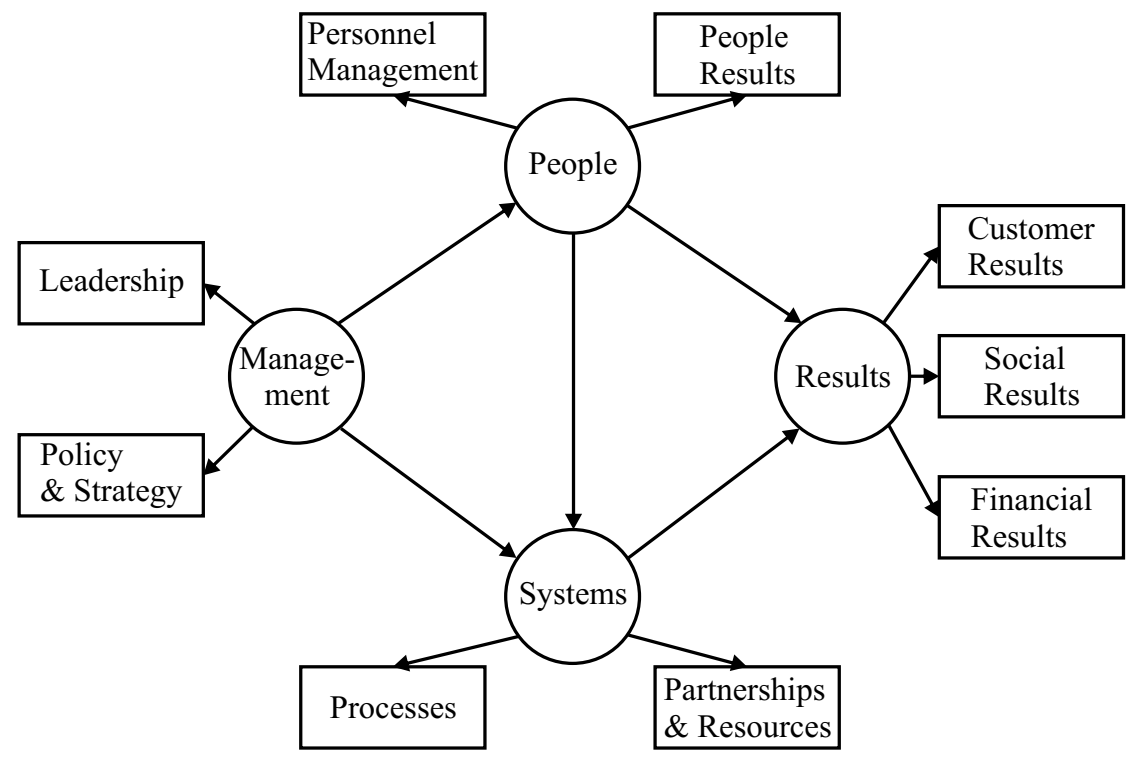

Thus, DBEI constitutes a proposal of how to link the nine areas of EFQM Excellence Model together in order to explain the interrelationship between them. The explanation of these linkages bases upon the following assumptions:

1. Quality of management is the overall cause of business excellence.

2. Good results are a function of both the effective use of the system and the intellectual capital in the company.

3. Quality of people influences the results directly and indirectly through the systems.

The assumptions are in good accordance with TQM literature, especially with recent findings about the role of quality of management and the interrelationship between processes and people management in the most successful organizations (Feigenbaum and Feigenbaum, 2003; Oakland and Oakland, 1998; Eskildsen, Dahlgaard, 2000; Prabhu, Appleby, Yarrow and Mitchell, 2000). Oakland and Oakland stress that effective people management is increasingly becoming a primary concern for organizations striving for business success. Also the structure of DBEI reflects that managers perform their leadership by empowerment and by encouraging people commitment and participation.
TOWARDS BUSINESS EXCELLENCE

Rafał Haffer

Figure 1.

The Danish Business

Excellence Index

Source:

Kristensen $e t$ al.

(2001a) 
TOWARDS BUSINESS EXCELLENCE

Rafał Haffer

Figure 2.

Results for the EFQM Excellence Model indicators for (a) the whole sample and (b) three subsamples

The Danish Business Excellence Model is estimated as a structural equation model by partial least squares (PLS). This estimation technique results in observation per company of all the elements of the model. Consequently, the level for each of the four constructs may be studied at the aggregate level, split into the nine components from the EFQM model or studied at the operational level by using the scores of the individual questions achieved on a 0-100 scale (Kristensen, Juhl and Eskildsen, 2003). This paper concentrates on the results at the aggregate level.

\section{Polish companies' progress towards excellence}

Figure 2 shows the results of CEOs' self-assessment indicating the efforts Polish companies make in the nine EFQM model areas in the four sections: for all examined firms $(\mathrm{N}=79)$, for firms applying the Balanced Scorecard, Excellence Model or TQM $(\mathrm{N}=8)$, for firms applying ISO $(\mathrm{N}=35)$ and for firms not applying a holistic leadership model $(\mathrm{N}=36)$. It appears from the data that despite the fact that the majority of Polish companies do not apply the Business Excellence Model as a coherent concept, many of them undertake actions in most EFQM model domains.

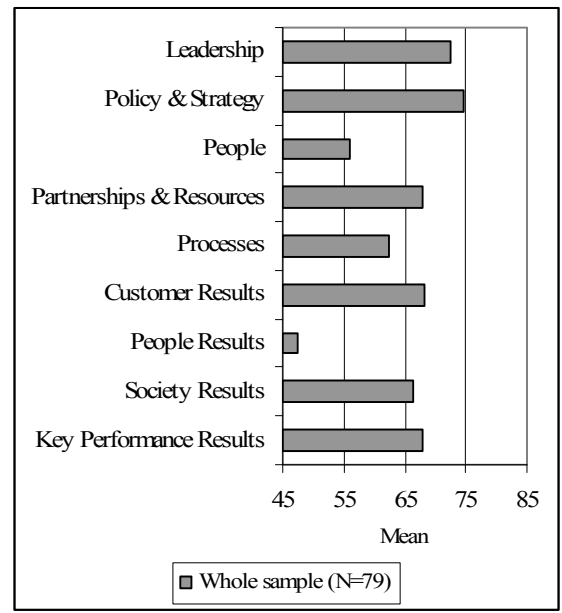

(a)

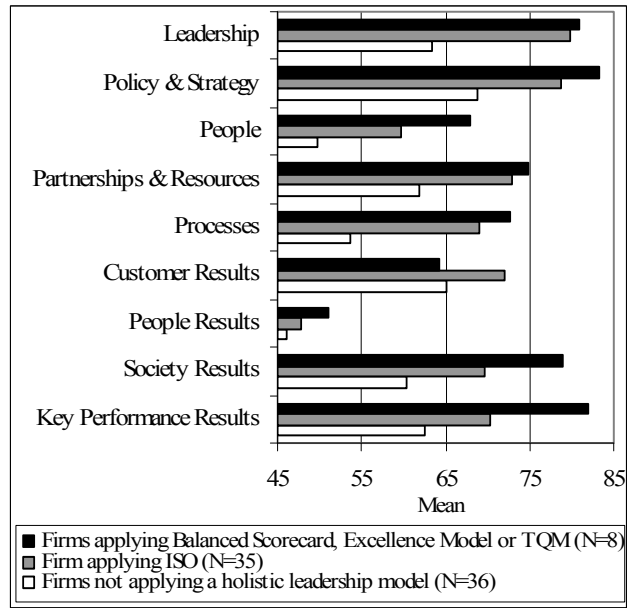

(b)

As regards the whole sample (figure 2a), the results indicate that Polish companies obtained not excellent but at the outmost average scores. They range from 47 to 75 points. Polish companies are perceived by managers as quite well led and provided with sufficiently clear and commonly communicated strategies. It is good information since the quality of management is an overall factor that affects business excellence. However, it appears that managers in Polish companies put considerable emphasis on partnerships \& resources and processes, but they 
neglect people. Therefore, it is no surprise that enablers do not produce good results in all of the four results domains. Key performance results and customer results were given the same score of 68 points and society results - 66 points since people results were assessed at 47 points. It is evident that people management constitutes a weak point of Polish companies.

Figure $2 \mathrm{~b}$ shows that companies applying an overall management model achieve a higher score in all of the nine areas of self-assessment than companies which do not apply such a model. Firms applying the Balanced Scorecard, Excellence Model or TQM are most advanced in business excellence initiatives, obtaining the highest scores for eight out of nine EFQM constructs (scores from 51 to 83). In fact, only in the field of customer results, ISO firms got the highest score.

In Table 2 the correlations between the EFQM Excellence Model indicators and performance variable (FTP) are given. It can be seen from the data that business excellence initiatives in most EFQM model areas stimulate total performance of examined companies which is proved by high and statistically significant correlations. However, in the case of three variables, namely, people, people results and customer results, there are no significant relationships with FTP. A low score of people results can be partly explained by a high and significant correlation between this variable and people $(r=0,81, p<=0,05)$, which confirms the aforementioned statement of a bad condition of people management in Polish companies. A low score for customer results in the whole sample is presumably reduced by poor accomplishments in that field of non management model firms $(\mathrm{N}=36)$. Generally, the results shown in Table 2 indicate again that companies applying a holistic management model achieve, on average, better results than other companies, which is confirmed by a higher correlation coefficients despite the fact that some of them are not significant.

\begin{tabular}{lccc}
\hline \multirow{2}{*}{$\begin{array}{c}\text { EFQM } \\
\text { Excellence Model indicators }\end{array}$} & $\begin{array}{c}\text { Whole sample } \\
(\mathrm{N}=79)\end{array}$ & $\begin{array}{c}\text { Management Mod- } \\
\text { el firms (N=43) }\end{array}$ & $\begin{array}{c}\text { Non Management } \\
\text { Model firms (N=36) }\end{array}$ \\
\cline { 2 - 4 } & FTP & FTP & FTP \\
\hline Leadership & $0.32^{* *}$ & $0.36^{* *}$ & 0.27 \\
\hline Policy \& Strategy & $0.28^{* *}$ & $0.39^{* *}$ & 0.13 \\
\hline People & 0.15 & 0.11 & 0.19 \\
\hline Partnerships \& Resources & $0.29 * *$ & 0.21 & $0.38^{* *}$ \\
\hline Processes & $0.20^{*}$ & 0.19 & 0.18 \\
\hline Customer Results & 0.07 & 0.19 & -0.14 \\
\hline People Results & 0.06 & 0.03 & 0.10 \\
\hline Society Results & $0.52 \dagger$ & $0.57 \dagger$ & $0.45^{* * *}$ \\
\hline Key Performance Results & $0.78 \dagger$ & $0.82 \dagger$ & $0.75 \dagger$ \\
\hline
\end{tabular}

$* p<=0.1 ; * * p<=0.05 ; * * * p<=0.01 ; \dagger p<=0.001$
TOWARDS BUSINESS EXCELLENCE

\section{Rafał Haffer}


TOWARDS BUSINESS EXCELLENCE

Rafał Haffer

Figure 3.

Estimation results for Polish companies according to DBEI
Figure 3a shows the estimates of the Danish Business Excellence Model structure obtained for Polish companies. The standardised path coefficients indicate that an increase in the management index will have a positive effect on both the people index and the system index. The effect on the people index will be much higher than on the system index and, furthermore, the people index will be strongly related to systems but not to results. It means that Polish firms are at the stage of achieving their results more through system solutions than people management.

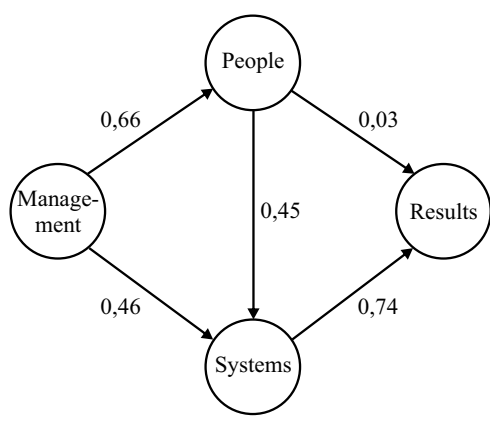

(a) (b)

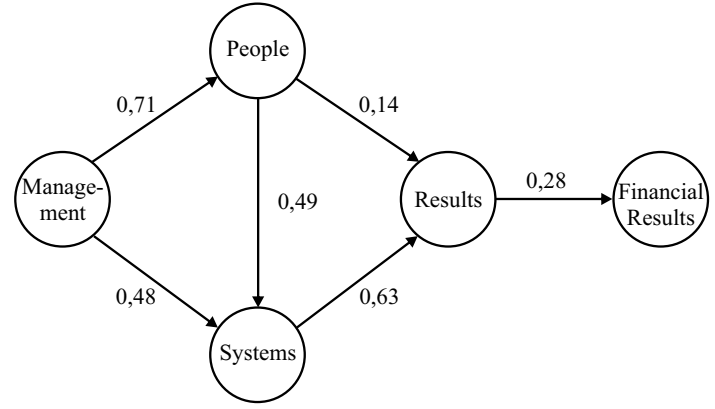

In fact, in the transformation period that started in the early 1990s, Polish companies have been giving priority to tangible resources development. They had to overcome the shortage of capital, technology, management structures, well-defined processes and procedures. Those technological, organizational, and, especially, infrastructural shortages are still a weak point of the whole of the Polish economy. They remain in interaction with companies' problems. Thus, as figure $3 \mathrm{a}$ clearly shows that a change in the people index can influence only indirectly the results of the company. However, such a situation suggests that there is still potential for future growth in Polish firms since experiences of companies from well-developed countries prove that the management focus has changed from tangible assets, like systems, to intangible assets, like relations, especially, relations with employees, to provide them with sustainable competitive advantages (see: e.g. Powell, 1995).

The data presented in Table 3 provide the evidence for the above statement. Table 3 shows the correlations between the Business Excellence variable (BE), performance variable (FTP) and explanatory variables (MM, EA, RCSS). It appears from the data that the firms which do not have real achievements in the field of proper relations with employees, which finds its expression in problems with employees' abandonment, achieve worse results than other companies. It is proved by a significant negative correlation between FTP and EA. 
Moreover, companies which put more emphasis on effective motivational systems, which are a part of people management, produce better results which is confirmed by a strong correlation between FTP and RCSS. Simultaneously, the use of the result dependent salary system is much more frequent in the firms which have achieved considerable progress towards excellence than in the remaining companies (strong correlation between RCSS and BE). The same positive relationship can be observed in the case of RCSS and MM which suggests that also firms applying any of the management models like Balanced Scorecard, Excellence Model, Malcolm Baldrige Model, ISO or TQM usually base their salary systems on results.

\begin{tabular}{|l|c|c|c|}
\hline$(\mathrm{N}=79)$ & $\begin{array}{c}\text { Firm's total } \\
\text { performance } \\
(\mathrm{FTP})\end{array}$ & $\begin{array}{c}\text { Employees' } \\
\text { Abandonment } \\
(\mathrm{EA})\end{array}$ & $\begin{array}{c}\text { Result Dependent } \\
\text { Salary System } \\
(\mathrm{RCSS})\end{array}$ \\
\hline Firm's total performance (FTP) & - & $-0.24^{*}$ & $0.32^{*}$ \\
\hline Management Model (MM) & $0.27^{*}$ & 0.01 & $0.34^{*}$ \\
\hline Business Excellence (BE) & $0.51 \dagger$ & -0.18 & $0.52 \dagger$ \\
\hline
\end{tabular}

$* p<=0.1 ; * * p<=0.05 ; * * * p<=0.01 ; \dagger p<=0.001$

What also appears from the data shown in Table 3 is that management models introduced and efforts undertaken in most areas of self-assessment according to the EFQM model do provide Polish companies with economic value which is confirmed by significant correlations between FTP and BE as well as FTP and MM. However, this economic value is not maximized, because an optimal benefit from the EFQM Excellence Model is not obtained. As Kristensen, Eskildsen and Juhl (2001b) state, any of the criteria in the model can be interrelated with the others so the emphasis in isolated areas is not sufficient to reach excellence. Since each result variable represents an important contribution, it is evident that companies have to tend towards the equilibrium of the needs of all stakeholders (Nabitz and Klazinga, 1999). According to the above mentioned conclusions, the main challenge for Polish companies is to put more attention to employees' needs in order to increase their satisfaction.

In Figure 3b the Business Excellence Index, as shown in Figure 3a, has been supplemented with an additional variable called financial results. When estimating the whole model in figure $3 \mathrm{~b}$ it can be seen that a standardised coefficient from the result index to financial index equals to 0.28 . This indicates that the result index reflects indeed the actual result in the company. At the same time it is justifiable to say that it is possible to use results gathered with the aid of Business Excellence Model methodology as a proxy for actual financial results of Polish companies.
TOWARDS BUSINESS EXCELLENCE

Rafał Haffer

Table 3.

Correlations between the Business Excellence variable (BE), performance variable (FTP) and explanatory variables (MM, EA, RCSS) 
TOWARDS BUSINESS EXCELLENCE

Rafał Haffer

\section{Conclusion}

It appears from the data presented in the paper that the efforts of Polish companies undertaken in most areas of self-assessment according to the EFQM model do provide them with economic value, which, however, could be maximized. Using the Danish Business Excellence Index methodology, the results show that people management is the weakest point of Polish companies. Current financial results are produced mainly by leadership and policy and strategy as well as by systems. Those are the areas in which Polish companies make currently special efforts. At the same time the areas which can be treated as potential for future growth are people, people results and customers results. In those ones the improvements should be made.

Nevertheless, the findings and implication should be interpreted with caution due to the main limitation of the study which is the sample size. Although the sample includes several service and manufacturing industries, the data obtained are based only on a sample of 79 Polish firms. Despite that limitation, however, the study does shed light on business excellence practices in Polish companies.

\section{References}

Conti, T. (1997), Organizational Self-Assessment, Chapman \& Hall, London.

Cronbach, L. (1951), "Coefficient alpha and the internal structure of tests", Psychometrica, 16, pp. 297-334.

Eskildsen, J.K., Dahlgaard, J.J. (2000), "A causal model for employee satisfaction”, Total Quality Management, Vol. 11, No. 8, pp. 1081-1094.

European Foundation for Quality Management (1999), EFQM Model for Business Excellence: Company Guidelines.

Feigenbaum, A.V., Feigenbaum, D.S. (2003), The Power of Management Capital. Utilizing the New Drivers of Innovation, Profitability, and Growth in a Demanding Global Economy, McGraw-Hill, New York.

Haffer, R. (2003), Systemy zarzadzania jakościq w budowaniu przewag konkurencyjnych przedsiębiorstw, Wydawnictwo UMK, Toruń.

Haffer, R. (2005), "TQM and imperfect imitability. The Polish case", in: paper presented at the $10^{\text {th }}$ World Congress for Total Quality Management, 22-24 August 2005, University of Manitoba, Winnipeg.

Hakes, C. (1997), The Corporate Self-Assessment Handbook, Chapman \& Hall, London.

Kristensen, K., Juhl, H.J. (1999), "Five years with quality awards in Denmark", TQM Magazine, Vol. 11, No. 2, pp. 80-83.

Kristensen, K., Juhl, H.J., Eskildsen, J. (2001a), "Benchmarking Excellence”, Measuring Business Excellence, 5, 1, pp. 19-23.

Kristensen, K., Juhl, H.J., Eskildsen, J. (2001b), "The criterion weights of the EFQM Excellence Model”, International Journal of Quality \& Reliability, Vol. 18, No. 8, pp. 783-795.

Kristensen, K., Juhl, H.J., Eskildsen, J. (2003), "Models that matter", International Journal of Business Performance Management, Vol. 5, No. 1, pp. 91-106. 
Nabitz, U.W., Klazinga, N.S. (1999), “EFQM approach to the Dutch quality award”, International Journal of Health Care Quality Assurance, Vol. 12 No. 2, pp. 65-70.

Oakland, J.S., Oakland, S. (1998), "The links between people management, customer satisfaction and business results", Total Quality Management, Vol. 9, Nos. 4\&5, pp. S185-S190.

Porter, L., Tanner, S. (1996), Assessing Business Excellence, Butterwoth-Heinemann, Oxford.

Powell, T.C. (1995), “Total Quality Management as Competitive Advantage: a Review and Empirical Study", Strategic Management Journal, Vol. 16, pp. 15-37.

Prabhu, V., Appleby, A. Yarrow, D., Mitchell, E. (2000), "The impact of ISO 9000 and TQM on best practice/performance", The TQM Magazine, Vol. 12, No. 2, pp. 84-91.

Ringle, C.M., Wende, S., Will, A. (2005), SmartPLS 2.0 (beta), University of Hamburg, Germany, available at: http://www.smartpls.de

van der Wiele, T., Dale, B., Williams, R. (2000), "Business improvement through quality management systems", Management Decision, Vol. 38, No. 1, pp. 19-23.

Westlund, A.H. (2001), "Measuring environmental impact on society in the EFQM system", Total Quality Management, Vol. 12 No. 1, pp. 125-135. 